\title{
EXPERIENTIAL LEARNING DALAM KEMAMPUAN APRESIASI PUISI MAHASISWA TADRIS BAHASA INDONESIA FITK IAIN SURAKARTA
}

\author{
Elen Inderasari \\ Tadris Bahasa Indonesia \\ IAIN Surakarta \\ inderasari85iain@gmail.com
}

\begin{abstract}
Abstrak: Penelitian ini mendeskripsikan penerapan metode experiental learning dalam apresiasi puisi, serta kemampuan apresiasi puisi mahasiswa di Tadris Bahasa Indonesia (TBI) IAIN FITK Surakarta. Metode experiental learning adalah metode belajar mengajar yang memungkinkan peserta didik untuk membangun pengetahuan dan keterampilan, nilai, dan sikap melalui pengalaman langsung. Oleh karena itu, metode ini akan bermakna saat mahasiswa berpartisipasi dalam kegiatan. Setelah itu, mereka dapat melihat aktivitas kritisnya, kemudian mereka mendapatkan pemahaman dan transfer dalam bentuk lisan atau tulisan sesuai dengan tujuan belajar. Dalam hal ini, metode experiential learning menggunakan pengalaman sebagai katalisator untuk membantu mahasiswa mengembangkan kapasitas dan kemampuannya dalam belajar. Penelitian ini merupakan penelitian deskriptif kualitatif. Jenis instrumen penelitian yang digunakan dalam penelitian ini adalah tes dan non-tes. Pengumpulan data dalam penelitian ini dilakukan dengan teknik dokumentasi, observasi, dan pengujian. Teknik pengumpulan data menggunakan 3 E (Experiencing, Enquiring, dan Examining). Hasil penelitian menunjukkan bahwa metode experiental learning mampu menerapkan pengalaman mahasiswa sebagai dasar untuk mengapresiasi puisi, serta tingkat apresiasi puisi yang dilakukan mahasiswa lebih baik, melalui pengalaman mereka dapat menerapkan metode experiential learning.
\end{abstract}

Kata kunci: apresiasi puisi, metode pembelajaran eksperiensial

Abstract: This research describes the application of the method of experiental learning activities in appreciation of poetry, as well as describe the ability of appreciation of poetry students learning in Indonesian Language Tadris (TBI) Department IAIN FITK of Surakarta. Experiential learning method is a method of teaching and learning processes that enable learners to build their knowledge and skills as well as his grades also attitude through his experiences directly. Therefore, these methods will be meaningful when learners participate in activities. After that, they looked at the critical activity, then they get an understanding and poured it in the form of oral or writing in accordance with the purpose of learning. In this case, experiential learning using the experience as a catalyst to help learners develop capacities and its ability in learning. This research included a qualitative descriptive study. This type of research instrument used in this study test and non-test. The collection of data in this study done with techniques of documentation, observation, and test. Data collection techniques using 3 E (Experiencing, Enquiring, and Examining). The results showed that experiental learning methods able to enable student-owned experience as the basis for the case of poetry, as well as the level of appreciation of poetry students better through, the experience they can apply the experiental learning method.

Keyword: apresiasi puisi, metode experiential learning 


\section{PENDAHULUAN}

Pembelajaran sastra sejak dulu sampai sekarang selalu menjadi permasalahan. Tentu saja permasalahan yang bersifat klasik tetapi hangat atau up to date. Umumnya yang selalu dikambinghitamkan adalah guru yang tidak menguasai sastra, murid-murid yang tidak apresiatif, dan buku-buku penunjang yang tidak tersedia di sekolah (Djojosuroto, 2006: 76).

Sastra dipandang sesuatu yang dihasilkan dan dinikmati, serta dapat disajikan dalam berbagai cara. Bahan pokok dalam pengajaran sastra adalah bahasa, baik bahasa lisan maupun bahasa tertulis. Salah satu bentuk karya sastra adalah puisi yang merupakan seni kreatif yang menggunakan bahasa sebagai medianya untuk menyampaikan pikiran dan perasaan. Puisi sebagai salah satu bentuk karya sastra dapat menawarkan suatu pesona kehidupan yang diangankan melalui berbagai unsur intrinsiknya, seperti peristiwa, tema, tokoh, latar, sudut pandang, dan pesan. Unsur pembangun itu menyebabkan karya sastra menjadi faktual.

Sastra dalam pengajaran dapat membantu pengajaran kebahasaan, karena sastra dapat meningkatkan keterampilan dalam berbahasa. Sastra dapat membantu pendidikan secara utuh karena sastra dapat meningkatkan pengetahuan budaya, pengembangan cipta, rasa, dan karsa, menunjang pembentukan watak, mengembangkan kepribadian, memperluas wawasan kehidupan dan pemberi kesejukan dan ketenangan hati bagi kehidupan manusia. Meskipun demikian, pengajaran sastra khususnya puisi masih menjumpai banyak kesulitan yang menyebabkan kemampuan apresiasi puisi siswa rendah (Djojosuroto, 2006a: 85).

Dari hasil refleksi awal bahwa kemampuan mahasiswa semester 2 TBI dalam mengapresiasi puisi masih rendah dan sangat memprihatinkan. Mahasiswa mengalami kesulitan memahami makna puisi. Kesulitan yang dihadapi mahasiswa itu ditandai dengan beberapa hal, seperti: (1) kesulitan menemukan unsur pembangun puisi yang meliputi unsur fisik dan unsur batin, (2) kesulitan dalam mengidentifikasi jenis-jenis puisi, dan (3) kebingungan dalam memahami bahasa puisi, karena bahasa puisi yang berbingkai dan dirangkai dalam konteks yang sulit dicerna maknanya. Rendahnya kemampuan mahasiswa dalam mengapresiasi puisi disebabkan kurang efektifnya pembelajaran yang berlangsung. Ketidakefektifan itu disebabkan oleh kurang tepatnya strategi dan metode yang diterapkan dosen dalam pembelajaran. Sering proses pembelajaran masih bersifat tradisional, dalam arti penyampaian materi perkuliahan hanya dengan berceramah (teacher centered). Selain itu, pembelajaran dengan model perkuliahan yang lebih ditekankan pada presentasi mahasiswa, sehingga mahasiswa kurang mendapat kesempatan mengembangkan potensi yang ada pada dirinya untuk melakukan konstruksi pengetahuan dan pengembangan pengetahuan menjadi sebuah produk pengetahuan baru.

Salah satu metode pembelajaran yang mengacu pada komponen apresiasi puisi adalah metode pembelajaran Experiential Learning. Metode pembelajaran experiential learning merupakan konsep belajar yang memberi kesempatan kepada mahasiswa terlibat langsung dalam proses penemuan dan pembentukan pengetahuan. Metode pembelajaran "experiential learning” dikembangkan oleh David Kolb sekitar awal tahun 1980-an. Dalam Experiential Learning, pengalaman mempunyai peranan sentral dalam proses belajar. Adapun tujuan dari metode pembelajaran ini yaitu untuk mempengaruhi siswa dengan tiga cara, yaitu: (1) mengubah struktur kognitif, (2) mengubah sikap, (3) memperluas keterampilan-keterampilan yang telah ada (Baharuddin \& Wahyuni, 2007: 164165).

Mengingat pentingnya kemampuan apresiasi puisi bagi mahasiswa calon guru bahasa Indonesia, maka peneliti memandang perlu melakukan suatu perbaikan pembelajaran, karena secara umum kemampuan siswa mengapresiasi puisi masih rendah. Istilah apresiasi berasal dari 
bahasa Latin apresiatif yang berarti mengindahkan atau menghargai. Selanjutnya, apresiasi menurut Gove mengandung makna (1) pengenalan melalui perasaan atau kepekaan batin, (2) pemahaman dan pengakuan terhadap nilai-nilai keindahan yang diungkapkan pengarang (Nurhadi, 2005: 78). Disick (Waluyo, 2002: 45) menyebutkan adanya 4 tingkatan apresiasi yaitu (1) tingkat menggemari, (2) tingkat menikmati, (3) tingkat mereaksi, dan (4) tingkat produktif. Apresiasi puisi berarti kemampuan atau keterampilan yang dimiliki tiap orang dalam memahami makna puisi. Objek apresiasi pada dasarnya adalah nilai-nilai dan makna yang terkandung dalam teks. Mengapresiasikan puisi berarti kesanggupan dalam mengenal, memahami, menghargai, menilai, dan memberi makna terhadap puisi yang dibaca (Djojosuroto, 2006b: 29).

Apresiasi seseorang terhadap puisi dapat dikembangkan dari tingkat sederhana ke tingkat yang tinggi. Apresiasi tingkat pertama terjadi apabila seseorang memahami atau merasakan pengalaman yang ada dalam sebuah puisi. Berapresiasi tingkat kedua terjadi apabila daya intelektual pembaca bekerja lebih giat. Pembaca mulai bertanya pada dirinya tentang makna pengalaman yang diperoleh, pesan yang disampaikan pengarang dan hal yang tersembunyi di balik alur puisi. Apresiasi tingkat ketiga pembaca menyadari hubungan karya sastra dan dunia luarnya, sehingga pemahamannya pun lebih luas dan mendalam.

Sementara itu, menurut Squire dan Taba (dalam Jihad \& Haris, 2008: 1) menyimpulkan bahwa sebagai suatu proses, apresiasi melibatkan tiga aspek inti yang meliputi: (1) aspek kognitif, (2) aspek emotif, (3) aspek evaluatif. Aspek kognitif berkaitan dengan keterlibatan intelektual pembaca dalam memahami unsurunsur kesastraan dan keterlibatan emosi (rasa) pembaca dalam upayanya menikmati unsur-unsur keindahan teks sastra. Aspek evaluatif berkaitan dengan kegiatan memberikan penilaian terhadap baik-buruk, indah-tidak indah, sesuai-tak sesuai, dan sejenisnya, yang secara inheren dan personal dimiliki oleh setiap pembaca.

Manfaat apresiasi puisi, sebagai hasil cipta yang mengandung aspek-aspek pengalaman manusia, puisi mampu memberikan berbagai manfaat kepada pembacanya. Horace (dalam Jihad \& Haris, 2008: 19) mengatakan bahwa fungsi dan sifat sastra adalah "dulce et utile', indah dan bermanfaat. Dengan keindahannya, puisi dapat memberikan hiburan yang menyenangkan. Akan tetapi, Wellek dan Warren (dalam Darmawan, 1999: 19) mengingatkan bahwa hiburan yang diperoleh dari kegiatan membaca puisi bukanlah kesenangan fisik semata-mata, melainkan hiburan dan kesenangan yang lebih tinggi, yaitu kontemplasi. Adapun manfaatnya ialah keseriusan yang menyenangkan, keseriusan estetis, dan keseriusan persepsi.

Metode pembelajaran experiential learning dikembangkan David Kolb sekitar awal 1980-an. Metode ini menekankan pada sebuah metode pembelajaran yang holistik dalam proses belajar. Dalam experiential learning, pengalaman mempunyai peran sentral dalam proses belajar. Istilah "experiential" di sini untuk membedakan antar teori belajar kognitif yang cenderung menekankan kognisi lebih dari afektif, dan teori belajar behavior yang menghilangkan peran pengalaman subjektif dalam proses belajar (Kolb dalam Baharuddin \& Wahyuni, 2007: 165).

Experiential learning dapat didefinisikan sebagai tindakan untuk mencapai sesuatu berdasarkan pengalaman yang secara terus menerus mengalami perubahan guna meningkatkan keefektifan dari hasil belajar itu sendiri. Tujuan dari metode pembelajaran experiential learning adalah untuk mempengaruhi siswa dengan tiga cara meliputi, (1) mengubah struktur kognitif siswa, (2) mengubah sikap siswa, (3) memperluas keterampilan-keterampilan siswa yang telah ada (Johnson \& Johnson dalam Baharuddin \& Wahyuni, 2007: 165). Metode experiential learning didasarkan pada beberapa pendapat sebagai berikut.

1. Pembelajar dalam belajar akan lebih baik ketika mereka terlihat secara langsung dalam 
pengalaman belajar.

2. Adanya perbedaan-perbedaan secara individu dalam hal gaya yang disukai.

3. Ide-ide dan prinsip-prinsip yang dialami dan ditemukan pembelajar lebih efektif dalam pemerolehan bahan ajar.

4. Komitmen peserta dalam belajar akan lebih baik ketika mereka mengambil tanggung jawab dalam proses belajar mereka sendiri, dan

5. Belajar pada hakikatnya melalui suatu proses.

Menurut Keeton and Tate (dalam Trianto, 2007: 43) mengatakan bahwa belajar melalui pengalaman mengacu pada learning in wich the learners is directly in touch with the realities being studied. Belajar melalui pengalaman melibatkan siswa secara langsung dalam masalah atau isu yang dipelajari.

Metode experiential learning adalah suatu metode proses belajar mengajar yang mengaktifkan pembelajar untuk membangun pengetahuan dan keterampilan serta nilainilainya juga sikap melalui pengalamannya secara langsung. Oleh karena itu, metode ini akan bermakna tatkala pembelajar berperan serta dalam melakukan kegiatan. Setelah itu, mereka memandang kritis kegiatan tersebut, kemudian mereka mendapatkan pemahaman serta menuangkannya dalam bentuk lisan atau tulisan sesuai dengan tujuan pembelajaran. Dalam hal ini, experiential learning menggunakan pengalaman sebagai katalisator untuk menolong pembelajar mengembangkan kapasitas dan kemampuannya dalam pembelajaran. Pengajaran berdasarkan pengalaman memberi mahasiswa serangkaian situasi belajar dalam bentuk keterlibatan pengalaman sesungguhnya yang dirancang oleh dosen. Cara ini mengarahkan para mahasiswa dalam hal memperoleh lebih banyak pengalaman dengan cara keterlibatan secara aktif, dibandingkan dengan bila mereka hanya melihat materi atau konsep. Perbedaan mendasar antara experiential learning dengan metode pembelajaran yang bersifat tradisional yaitu:

\section{1) Briefing}

Briefing adalah tahap proses pengarahan pada individu atau kelompok sebelum melakukan pengarahan. Teknik-teknik yang perlu dikuasai yaitu sebagai berikut.

Tabel 1. Perbedaan Experiential Learning dan Tradisional Content Based Learning.

\begin{tabular}{|l|l|}
\hline \multicolumn{1}{|c|}{ Experiential Learning } & \multicolumn{1}{c|}{ Traditional Content-Based Learning } \\
\hline 1. Aktif & 1. Pasif \\
2. Bersandar pada penemuan individu & 2. Bersandar pada keahlian mengajar. \\
3. Partisipatif berbagai arah & 3. Otokratis, satu arah \\
4. Dinamis dan belajar dengan & 4. Terstruktur dan belajar dengan mendengar. \\
melakukan. & 5. Cakupan terbatas dengan sesuatu yang baku. \\
5. Bersifat terbuka & 6. Terfokus pada tujuan belajar yang khusus. \\
6. Mendorong untuk menemukan & \\
\hline sesuatu & \\
\hline
\end{tabular}

(www.ialf.edu/kipbipa/papers/cahyaniIsah.doc-)

Kerangka Kerja Experiential Learning

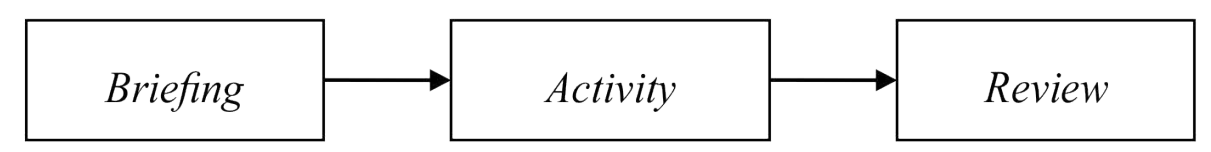

Gambar 1. Kerangka Kerja Experiential Learning 
a. Setting dan Conditioning (Pengaturan dan Pengkondisian)

Salah satu cara untuk memunculkan pemahaman adalah pengaturan situasi. Oleh karena itu, hal utama yang perlu diperhatikan adalah pemahaman yang mendalam tentang kegiatan yang akan dilakukan sesuai dengan skenario pembelajaran.

b. Directing

Directing adalah proses pengarahan pada pembelajar tentang materi kegiatan yang akan dilakukan.

Hal-hal yang perlu diperhatikan saat melakukan pengarahan antara lain.

c. Motivating

Pemberian motivasi dilakukan ketika pembelajar mengalami penurunan semangat.

\section{2) Activity}

Activity adalah tahap pembelajar untuk melaksanakan kegiatan sesuai dengan briefing yang telah diberikan.

\section{3) Review}

Review adalah tahap pembelajar dibantu oleh pengajar untuk melihat dan memandang secara kritis (apa, mengapa, atas dampak yang terjadi) diikuti dengan menarik pelajaran dari pengalaman tersebut untuk diterapkan dalam kehidupan. Pada tahap ini diharapkan terjadi proses experiential learning pada pembelajar.

Penerapan metode experiential learning dalam mengapresiasi puisi dilakukan melalui tiga tahap yaitu briefing, activity, dan review. Berikut ini adalah kerangka kerja penerapan experiential learning dalam mengapresiasi puisi.

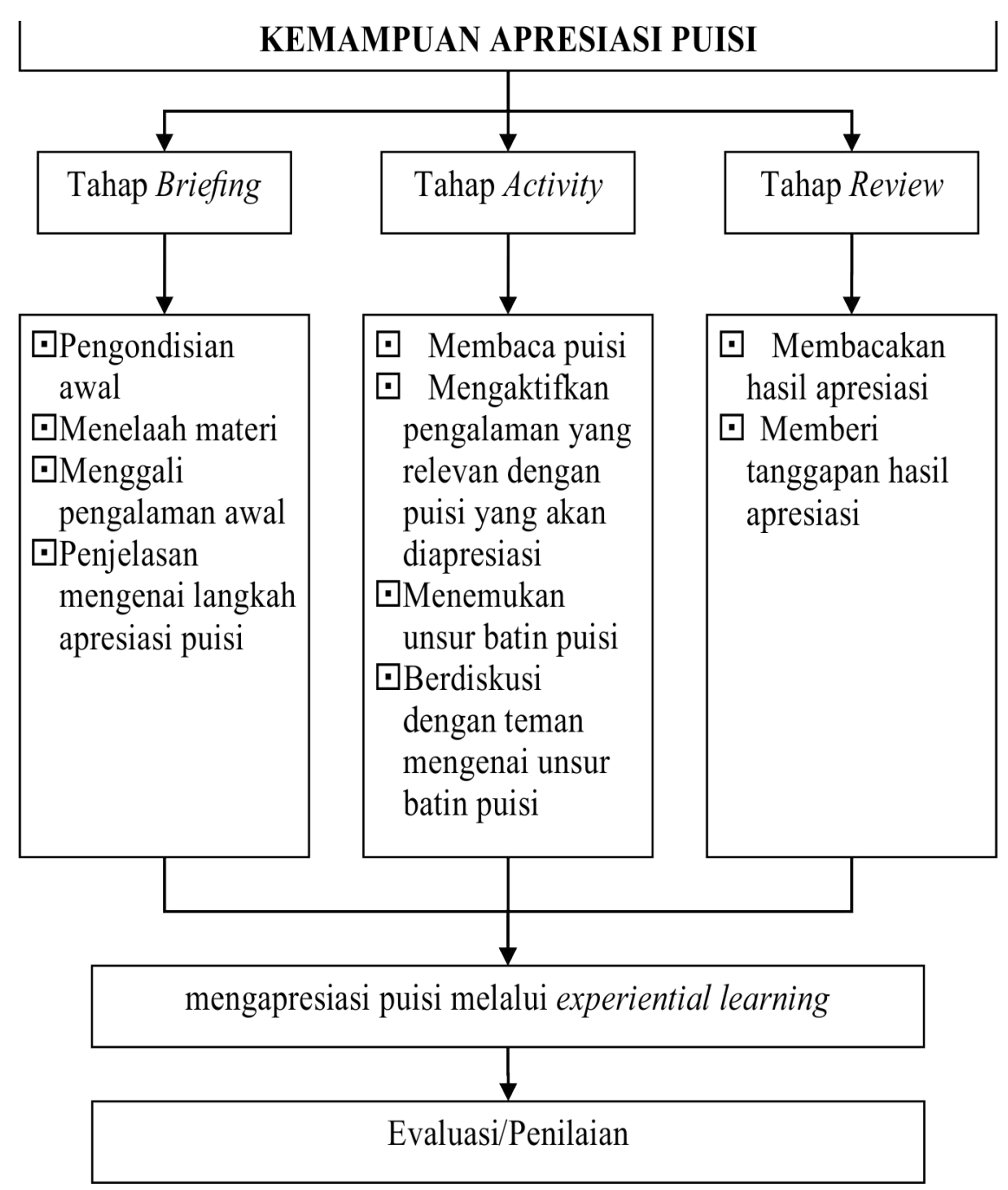




\section{METODE}

Penelitian ini dilakukan dalam kegiatan perkuliahan mata kuliah menyimak teknis estetik materi puisi semester 2 mahasiswa Tadris Bahasa Indonesia FITK IAIN Surakarta. Berdasarkan karakteristik masalah yang diteliti, maka jenis pendekatan penelitian yang digunakan adalah deskriptif kualitatif. Peneliti menekankan catatan dengan deskripsi kalimat yang rinci, lengkap dan mendalam yang menggambarkan situasi sebenarnya guna mendukung penyajian data (Sutopo, 2006: 40).

Rancangan penelitian ini dosen mengamati hasil penerapan metode experiental learning dalam pembelajaran dan kemampuan apresiasi puisi mahasiswa dengan metode experiental learning. Kegiatan berlangsung selama 4 bulan. Jenis instrumen penilaian yang digunakan dalam penelitian ini, yaitu (1) tes dan (2) non tes. Tes merupakan himpunan pertanyaan yang harus dijawab, harus ditanggapi, atau tugas yang harus dilaksanakan oleh seseorang yang dites. Tes digunakan untuk mengukur sejauh mana mahasiswa telah menguasai pelajaran yang disampaikan terutama meliputi aspek pengetahuan dan keterampilan. Penilaian non tes merupakan prosedur yang dilalui untuk memperoleh gambaran mengenai karakteristik minat, sifat dan kepribadian (Jihad \& Haris, 2008: 67). Bentuk tes yang digunakan dalam penelitian ini adalah tes formatif (esai) dan tes perbuatan (tindakan). Bentuk non tes yang digunakan melalui pedoman pengamatan (observatif).

Jihad \& Haris (2008: 68) menyatakan bahwa tes perbuatan merupakan tugas yang pada umumnya berupa kegiatan praktik atau melakukan kegiatan yang mengukur keterampilan. Tes perbuatan digunakan menilai hasil belajar pada ranah psikomotoris. Tes perbuatan dalam penelitian ini difokuskan untuk menilai performance, tes perbuatan dalam penelitian ini difokuskan untuk menilai performance siswa dalam membaca puisi. Untuk melakukan pengamatan, terlebih dahulu perlu menentukan aspek-aspek yang dinilai sekaligus kriteria penilaiannya.

Pedoman pengamatan (observasi) merupakan pengamatan partisipatif dilakukan oleh orang yang terlibat secara aktif dalam proses pelaksanaan tindakan. Pengamatan tersebut dapat dilaksanakan dengan pedoman pengamatan (format, daftar cek), observasi di kelas, checklist kegiatan belajar mengajar, catatan lapangan, jurnal harian dan alat perekam elektronik cf. Mills (dalam Susilo, 2008: 71).

Pedoman pengamatan (observasi), yaitu alat penilaian yang pengisiannya dilakukan oleh guru atas dasar pengamatan terhadap perilaku siswa, baik secara perorangan maupun kelompok, di kelas maupun di luar kelas (Jihad \& Haris, 2008: 69). Bentuk pedoman pengamatan yang digunakan dalam penelitian ini adalah checklist kegiatan belajar mengajar, dan format lembar observasi proses kegiatan Apresiasi puisi. Pedoman pengamatan (observasi) digunakan untuk mengukur kemampuan mahasiswa pada ranah afektif.

Pengumpulan data penelitian ini dilakukan dengan menggunakan banyak cara dari berbagai sumber, sehingga dikatakan bahwa pengumpulan datanya menggunakan triangulasi. Menurut Wolcott (dalam Susilo, 2008: 58) kekuatan penelitian kualitatif adalah pada tirangulasi ini, yaitu adanya pengumpulan informasi dengan berbagai cara.

Menurut Mills (dalam Susilo 2008: 59) dari segi teknik pengumpulan data kualitatifnya, ada tiga teknik yang dapat dipilih oleh peneliti untuk mengumpulkan data yang disebut sebagai $3 \mathrm{E}$ (experiencing, enquiring, dan examining).

1. Experiencing yaitu pengumpulan data melalui pengalaman sendiri, terlibat dan berpartisipasi dalam kegiatan, atau membuat catatan lapangan. Teknik pengumpulan datanya dapat berupa (a) observasi partisipan sebagai partisipan aktif; (b) pengamat aktif yang khusus; dan (c) pengamat pasif.

2. Enquiring yaitu teknik pengumpulan data melalui pertanyaan oleh peneliti. Hal itu 
dapat berupa (a) wawancara informal, (b) wawancara formal terstruktur; (c) kuesioner; (d) skala sikap yang mungkin berupa skala Likert atau skala perbedaan makna; dan (e) tes baku.

3. Examining yaitu teknik pengumpulan data melalui pembuatan dan pemanfaatan catatan yang dapat berupa (a) data arsip; (b) jurnal; (c) peta; (d) audiotape dan videotape; (e) artefak; dan (f) catatan lapangan.

Pengumpulan data dilakukan dengan teknik dokumentasi, observasi, dan tes. Teknik dokumentasi dilakukan untuk mengetahui kemampuan masing-masing mahasiswa sebagai dasar pembagian kelompok. Teknik observasi digunakan untuk merekam proses belajar mengajar dengan penerapan metode experiental learning berdasarkan instrumen observasi, sedangkan tes digunakan untuk mengetahui kualitas hasil belajar.

Seperti yang dikemukakan sebelumnya, ada tiga macam metode yang diterapkan dalam penelitian ini menurut tahapannya, yaitu (1) metode pengumpulan data, (2) metode analisis data, (3) metode penyajian hasil analisis data (Arikunto, 2006: 365). Teknik analisis data dalam penelitian ini dilaksanakan secara deskriptif kualitatif dengan langkah-langkah yang terdiri dari (1) mengumpulkan data verbal dan nonverbal dari hasil kegiatan pembelajaran; (2) mencatat, menghimpun dan menyeleksi data yang telah dikumpulkan; (3) menranskrip data-data yang telah dikumpulkan; (4) menerjemahkan data temuan baik dari instrumen tes dan nontes; (5) melakukan deskripsi analisis data; (6) menyimpulkan hasil analisis.

\section{HASIL DAN PEMBAHASAN}

Berdasarkan kajian teoretis dan deskripsi hasil penelitian yang telah dipaparkan di awal, penerapan metode Experiential Learning dalam kegiatan apresiasi puisi pada mahasiswa TBI FITK IAIN Surakarta.

\section{Penerapan Metode Experiental Learning dalam Kegiatan Apresiasi Puisi}

Berdasarkan hasil observasi terhadap jalannya proses pembelajaran, maka dapat diperoleh gambaran mengenai penerapan metode Experiental Learning dalam kegiatan apresiasi puisi karya Taufik Ismail, Sapardi Djoko Damono, W.S. Rendra masih rendah dan belum tepat. Hal tersebut ditandai dengan ketidaksesuaian dalam pemaknaan tiap diksi di dalam puisi dan pesan yang disampikan oleh penyair belum mampu ditangkap secara menyeluruh.

Adapun penerapan metode eksperimental learning lebih mendasarkan pada kegiatan di mana mahasiwa diberi kesempatan untuk memilih puisi dan dibentuk kelompok-kelompok kecil dengan membentuk diskusi kelompok, selanjutnya penerapan metode experiential learning bertujuan untuk meningkatkan kemampuan mahasiswa dalam mengaktifkan pengalaman yang dimiliki sebagai dasar mengapresiasi puisi, kemudian dosen memberikan reinforcement terhadap argumentasi mahasiswa dan memberi penghargaan pada masing-masing kelompok berdasarkan urutan tingkat kerja sama yang paling baik selanjutnya dosen melaksanakan penilaian pada aspek psikomotorik.

Kenyataanya ditemukan adanya beberapa permasalahan yang dilatar belakangi oleh masalah belum optimalnya hasil kerja kelompok dan rendahnya pemahaman materi tentang apresiasi puisi yang difokuskan pada kegiatan menemukan unsur batin puisi. Kekurangan hasil kerja kelompok terjadi karena (1) tidak semua tugas dikerjakan tepat sesuai jawaban, (2) kurang relevannya hubungan antara jawaban dan pertanyaan yang disajikan, (3) jawaban kurang lengkap atau tidak sesuai dengan permintaan dalam pertanyaan, dan (4) kesalahan dalam menarik kesimpulan hasil diskusi.

Berdasarkan hasil analisis penilaian secara individu maupun kelompok, maka kegiatan belajar mengajar yang telah berlangsung dengan baik dan lebih menyenangkan. Hal tersebut dipengaruhi 
oleh penerapan metode experiential learning yang memberi kesempatan pada mahasiswa untuk terlibat aktif dalam setiap kegiatan pembelajaran. Dalam metode experiential learning pengalaman merupakan dasar untuk mengonstruksikan pengetahuan baru. Hal tersebut terwujud dari kegiatan mahasiswa dalam mengaitkan kehidupan dalam puisi dengan kehidupan nyata. Hal tersebut sedikit banyak dipengaruhi oleh penerapan metode experiential learning yang membiasakan mahasiswa untuk mengaktifkan maupun mengembangkan kemampuan yang dimiliki sebagai bentuk proses pembelajaran. Hal tersebut dipengaruhi oleh penerapan metode experiential learning yang memberi kesempatan pada siswa untuk terlibat aktif dalam setiap kegiatan pembelajaran.

Kemampuan Mahasiswa Pembelajaran Apresiasi Puisi dengan Metode Eksperimental Learning

Hasil analisis dan penilaian secara individu maupun kelompok, dalam kegiatan belajar mengajar telah berlangsung dengan cukup baik, walaupun kualitas hasil belajar belum sesuai dengan yang diharapkan. Hal tersebut disebabkan belum optimalnya hasil kerja kelompok dan rendahnya pemahaman materi tentang apresiasi puisi yang difokuskan pada kegiatan menemukan unsur batin puisi. Kekurangan hasil kerja kelompok terjadi karena: (1) tidak semua tugas dikerjakan tepat sesuai jawaban, (2) kurang relevannya hubungan antara jawaban dan pertanyaan yang disajikan, (3) jawaban kurang lengkap atau tidak sesuai dengan permintaan dalam pertanyaan, dan (4) kesalahan dalam menarik kesimpulan hasil diskusi.

Berdasarkan hasil analisis penilaian secara individu maupun kelompok, maka kegiatan belajar mengajar yang telah berlangsung dengan baik dan lebih menyenangkan. Berdasarkan hasil analisis data penelitian yang telah dilakukan, hasilnya dapat ditafsirkan sebagai berikut.

Hasil analisis data pada pretest yang telah dilakukan sebelum adanya metode experiental learning dalam pembelajaran apresisiasi puisi, jumlah mahasiswa yang nilainya $>65$ atau mencapai kategori tuntas adalah 19 anak atau mencapai $(48,72 \%)$, sedangkan jumlah siswa yang nilainya $<65$ ada 20 anak atau mencapai (51,78\%). Hal ini menunjukkan kualitas hasil belajar apresiasi puisi belum berhasil. Adapun hal-hal yang menyebabkan kualitas hasil belajar dan proses pembelajaran belum mencapai tingkat keberhasilan yaitu sebagai berikut.

a. Pemahaman materi puisi yang dianalisis masih rendah.

b. Mahasiswa terbiasa dengan pembelajaran secara konvensional, sehingga perlu beradaptasi dengan metode pembelajaran yang baru.

c. Keaktifan mahasiswa dalam keberanian bertanya masih rendah, sehingga kegiatan diskusi belum berjalan dengan baik.

d. Kegiatan pembelajaran belum sesuai dengan yang direncanakan.

e. Mahasiswa masih kurang teliti dalam menganalisis makna puisi.

f. Pengelolaan alokasi waktu belum berjalan secara optimal.

g. Dosen kurang memberi resitasi/ umpan balik pada mahasiswa untuk menanyakan materi yang belum dipahami ataupun kesulitan yang dihadapi.

h. Suasana kelas kurang kondusif, sehingga berpengaruh pada konsentrasi mahaiswa yang dalam belajar.

Hasil analisis data dari delapan kelompok di dalam pembelajaran apresisasi puisi, enam kelompok sudah sikap aktif dan kemampuan apresiasi puisinya sudah memuaskan, terbukti dengan adanya kedekatan makna dalam mengganalisis diksi-diksi puisi, dan mampu menyampaikan maksud dari penyair tentang isi puisi tersebut, sedangkan dua kelompok masih kurang memuaskan, karena beda pemaknaan dalam menggungkapkan diksi-diksi di dalam puisi yang telah dianalisis. Berdasarkan analisis tersebut, dapat disimpulkan bahwa kemampuan mahasiswa dalam mengapresiasi puisi sedikit meningkat. Adapun hal-hal yang menyebabkan peningkatan kualitas hasil belajar apresiasi, hal 
tersebut dipengaruhi oleh beberapa hal, yaitu mahasiswa sudah mulai memahami makna puisi sebagai materi pembelajaran, adanya pengalaman dasar untuk mempermudah memahami makna puisi, ketepatan pemaknaan tiap diksi dalam puisi, sikap kritis, dan keberanian dalam kegiatan diskusi dan tanya jawab dalam mengembangkan kreativitas mahahasiswa.

Berdasarkan hasil angket yang disebarkan, penerapan metode experiential learning ditanggapi dengan sangat baik, di mana mahasiswa merasa tertarik dan senang mengikuti pembelajaran apresiasi puisi melalui metode tersebut. Hal itu disebabkan mahasiswa dapat berdiskusi, lebih mudah dalam mengemukakan pendapat sesuai dengan pengalaman dan pengetahuan yang dimilikinya. Ada berbagai upaya pembelajaran apresiasi puisi, di antaranya: (a) menerapkan metode experiential learning, (b) membentuk kegiatan diskusi kelompok dalam mengapresiasi puisi, (c) membiasakan siswa mengemukakan ide atau pendapatnya, sehingga mengurangi rasa bosan dalam mengikuti pembelajaran, (d) menemukan aspek yang digunakan sebagai indikator pencapaian dan (e) memusatkan kegiatan belajar pada mahasiswa.

\section{KESIMPULAN}

Dari hasil penelitian yang telah dilaksanakan dapat ditarik kesimpulan sebagai berikut.

1. Penerapan metode experimental learning lebih mendasarkan pada kegiatan mahasiswa dalam mengaktifkan pengalaman yang dimiliki sebagai dasar mengapresiasi puisi, adapun hal-hal yang meningkatan kualitas hasil belajar apresiasi dipengaruhi oleh beberapa hal, yaitu mahasiswa sudah mulai memahami makna puisi sebagai materi pembelajaran, adanya pengalaman dasar untuk mempermudah memahami makna puisi, ketepatan pemaknaan tiap diksi dalam puisi, sikap kritis dan keberanian dalam kegiatan diskusi dan tanya jawab dalam mengembangkan kreativitas mahahasiswa. Hal itu disebabkan mahasiswa dapat berdiskusi, lebih mudah dalam mengemukakan pendapat sesuai dengan pengalaman dan pengetahuan yang dimilikinya.

2. Kemampuan mahasiswa dalam mengapresiasi puisi sudah memuaskan, Adapun hal-hal yang menyebabkan peningkatan kualitas hasil belajar apresiasi dipengaruhi oleh beberapa hal, yaitu mahasiswa sudah mulai memahami ketepatan pemaknaan diksi dalam puisi yang dipunculkan penyair, adanya pengalaman dasar yang mereka miliki semakin mempermudah memahami makna puisi, ketepatan pemaknaan tiap diksi dalam puisi, munculnya sikap kritis dan keberanian dalam kegiatan diskusi dan tanya jawab dalam mengembangkan kreativitas mahahasiswa. Ada berbagai upaya dalam mengaktifkan mahasiswa dalam pembelajaran apresiasi puisi, di antaranya: (a) menerapkan metode experiential learning, (b) membentuk kegiatan diskusi kelompok dalam mengapresiasi puisi, (c) membiasakan siswa mengemukakan ide atau pendapatnya, sehingga mengurangi rasa bosan dalam mengikuti pembelajaran, (d) menemukan aspek yang digunakan sebagai indikator pencapaian dan (e) memusatkan kegiatan belajar pada mahasiswa.

\section{DAFTAR PUSTAKA}

Arikunto, S. (2006). Penelitian Tindakan Kelas. Jakarta: Bumi Aksara.

Baharuddin \& Wahyuni, E. N. (2007). Teori Belajar dan Pembelajaran. Yogyakarta: ArRuz Media.

Darmawan, T. (1999). Apresiasi Puisi, Konsep Dasar, Pendekatan dan Prosesnya. Malang: Universitas Negeri Malang Press.

Djojosuroto, K. (2006a). Analisa Teks Sastra dan Pengajarannya. Yogyakarta: Pustaka.

Djojosuroto, K. (2006b). Pengajaran Puisi, Analisis, dan Pemahaman. Bandung: Nuansa.

Jihad, Asep \& Haris, A. (2008). Evaluasi Pembelajaran. Yogyakarta: Multi Pressindo. 
Nurhadi. (2005). Membaca Cepat dan Efektif. Bandung: Sinar Baru Algesindo.

Susilo, H. dkk. (2008). Penelitian Tindakan Kelas. Malang: Bayumedia.

Sutopo. (2006). Metodologi Penelitian Kualitatif. Surakarta: Universitas Sebelas Maret Press.
Trianto. (2007). Model Pembelajaran Terpadu dalam Teori dan Praktik. Jakarta: Prestasi Pustaka.

Waluyo, H. J. (2002). Apresiasi Puisi. Jakarta: PT. Gramedia Pustaka Utama. 